\title{
An Intramolecular Cyclocarbonylation of Allenyl Sulfinimides by Molybdenum Carbonyl for the Synthesis of Bicyclic 3-Methylene-1-pyrrol-2-ones ${ }^{\dagger}$
}

\author{
Bomi Kim, Tae Hee Ha, Kyung Yong Jin, and Chan-Mo Yu* \\ Department of Chemistry, Sungkyunkwan University, Suwon 440-746, Korea \\ *Email: cmyu@chem.skku.ac.kr \\ Received March 16, 2011, Accepted April 1, 2011
}

Key Words : Allene, Carbocyclization, Lactam, Molybdenum carbonyls, Sulfinimide

Among a variety of synthetic methodologies for the construction of cyclic compounds, chemical transformations involving the use of transition metal complexes are some of the most attractive methodologies because reactions can directly construct complex molecules from relatively simple starting materials. ${ }^{1}$ As a consequence, many advances in the cyclization mediated by transition metals have been made through a variety of ways in synthetic strategy. ${ }^{2}$ Of particular interest is a cyclization strategy between carbonyl and unsaturated bonds to find practical way of chemical routes for the preparation of lactones mainly because the chemical process could dominate over the classical methods in simple trial. ${ }^{3}$ Structurally unique allenes are found in nature and play important biological and chemical roles. ${ }^{4}$ Recently allene moieties have been utilized as useful substrates for a variety of chemical transformations. ${ }^{5}$ Recently, we have disclosed our discovery of direct cyclization methods for the synthesis of bicyclic lactones using allenyl carbonyl compounds, ${ }^{6}$ cyclic compounds as part of the allylic transfer strategy utilizing an allene as substrates or intermediates. ${ }^{7}$ In particular, we demonstrated utility of allenyl hydrazones 1 in the construction of bicyclic lactams 2 using molybdenum carbonyl complexes. ${ }^{8}$

The characteristic features of this protocol in terms of chemical efficiency through a $[2+2+1]$-three component coupling process and structural features of products have

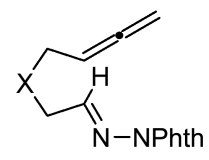

1

$\prod$ Asymmetric route

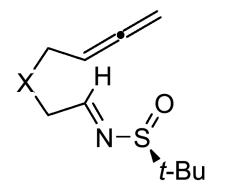

3

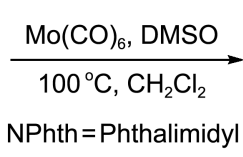

NPhth $=$ Phthalimidyl
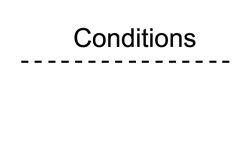

thategy.
Scheme 1. General strategy.

This paper is dedicated to Professor Eun Lee on the occasion of his honourable retirement.

2

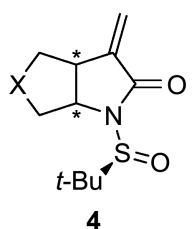

4 encouraged us to carry out further investigations to design asymmetric synthetic routes, which would expand utility of the method. As a consequence, we became quite interested in carrying out investigation with chiral allenyl sulfinimide $\mathbf{3}$ because it was expected to achieve chiral 3-methylene -1butyrolactam $\mathbf{4}$ as shown in Scheme 1. ${ }^{9}$

With this issue in mind, several allenyl sulfinimides were prepared by known method. ${ }^{10}$ As a starting point, the allenyl sulfinimide 3a $(\mathrm{X}=\mathrm{NTs})$ was selected as a model substrate to prove reactivity and diastereoselectivity.

The first study for preliminary experiments focused on the feasibility of 3a as a substrate for the cyclocarbonylation with molybdenum carbonyls to afford $\mathbf{4 a}$ as depicted in Scheme 1. Initial attempts to cyclocarbonylation of $\mathbf{3 a}$ under the previous conditions employed for simple allene-hydrazones indicated that the conversion to the corresponding lactam $4 \mathbf{a}$ could not be satisfied. We could not find any evidence for the formation of 4a. Surprisingly, reaction produced separable the desulfinated 5a (34\%) along 6a in a ratio of 3:1 (Table 1, entry 1). Unfortunately, reaction did not proceed below 90 ${ }^{\circ} \mathrm{C}$. We subsequently speculated that the introduction of molybdenum carbonyl derivatives might be needed to enhance

Table 1. Orienting experiments of cyclocarbonylation with 1a

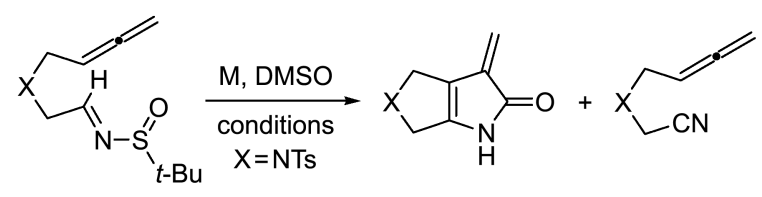

$5 a$

\begin{tabular}{|c|c|c|c|c|}
\hline Entry & $\mathrm{Mo}^{a}$ & Conditions & $5 \mathbf{a}: \mathbf{6 a}^{b}$ & Yield, $\%^{c}$ \\
\hline 1 & A & $\operatorname{DMSO}(10 \mathrm{eq}), 120^{\circ} \mathrm{C}, 6 \mathrm{~h}, \mathrm{CH}_{2} \mathrm{Cl}_{2}$ & $75: 25$ & 34 \\
\hline 2 & A & $\operatorname{DMSO}\left(10\right.$ eq), $90^{\circ} \mathrm{C}, 9 \mathrm{~h}, \mathrm{CH}_{2} \mathrm{Cl}_{2}$ & ND & trace \\
\hline 3 & A & $\operatorname{DMSO}(10 \mathrm{eq}), 120{ }^{\circ} \mathrm{C}, 9 \mathrm{~h}, \mathrm{PhCH}_{3}$ & $71: 29$ & 22 \\
\hline 4 & B & $\operatorname{DMSO}(10 \mathrm{eq}), 100^{\circ} \mathrm{C}, 6 \mathrm{~h}, \mathrm{CH}_{2} \mathrm{Cl}_{2}$ & ND & - \\
\hline 5 & B & $\operatorname{DMSO}(10 \mathrm{eq}), 100^{\circ} \mathrm{C}, 9 \mathrm{~h}, \mathrm{PhCH}_{3}$ & ND & - \\
\hline 6 & $\mathrm{C}$ & $\operatorname{DMSO}(10 \mathrm{eq}), 80^{\circ} \mathrm{C}, 6 \mathrm{~h}, \mathrm{CH}_{2} \mathrm{Cl}_{2}$ & $87: 13$ & 67 \\
\hline 7 & $\mathrm{C}$ & $\operatorname{DMSO}(10$ eq $), 80^{\circ} \mathrm{C}, 9 \mathrm{~h}, \mathrm{PhCH}_{3}$ & $83: 17$ & 41 \\
\hline 8 & $\mathrm{C}$ & DMSO (10 eq), $80^{\circ} \mathrm{C}, 9 \mathrm{~h}$, dioxane & $78: 22$ & 24 \\
\hline
\end{tabular}

${ }^{a} \mathrm{Mo}\left(1.5\right.$ equiv), $\mathrm{A}=\mathrm{Mo}(\mathrm{CO})_{6}, \mathrm{~B}=\mathrm{C}_{7} \mathrm{H}_{8} \mathrm{Mo}(\mathrm{CO})_{3}, \mathrm{C}=\mathrm{Mo}(\mathrm{CO})_{3}(\mathrm{DMF})_{3}$. ${ }^{b}$ Determined by ${ }^{1} \mathrm{H}$ NMR analysis of crude products. ${ }^{c}$ Refer to isolated and chromatographed yield of $\mathbf{5 a}$. 
reactivity. After surveying numerous conditions for orienting experiments as summarized in Table 1 , several key findings emerged as follows: i) the desired 4a was not produced under the various conditions appeared in Table 1; ii) the use of 1.5 equivalents of $\mathrm{Mo}(\mathrm{CO})_{3}(\mathrm{DMF})_{3}$ was required for optimal yield of $\mathbf{5 a} ;{ }^{11}$ iii) the introduction of DMSO as an additive proved to be crucial to promote reaction. Under optimal conditions (entry 6 in Table 1), the reaction was conducted by an addition of $\mathbf{3 a}$ (1 equiv) and DMSO (10 equiv) in $\mathrm{CH}_{2} \mathrm{Cl}_{2}$ at $20{ }^{\circ} \mathrm{C}$ to a solution of $\mathrm{Mo}(\mathrm{CO})_{3}(\mathrm{DMF})_{3}\left(1.5\right.$ equiv) in $\mathrm{CH}_{2} \mathrm{Cl}_{2}$ in a seal tube. After stirring at $20{ }^{\circ} \mathrm{C}$ for $30 \mathrm{~min}$, the reaction mixture was immediately immersed into a pre-heated oil bath at $80^{\circ} \mathrm{C}$. After $6 \mathrm{~h}$ at $80^{\circ} \mathrm{C}$, the reaction mixture was cooled to rt and then filtered through a sintered glass filter containing celite. Final purification was effected by column chromatography to yield $\mathbf{5 a}$ in $67 \%$ yield.

We soon realized that the synthesis of 3-methylene-1-pyrrol2-ones 5 might be useful because the utilization of dienes can be foreseen for many functional group transformations. With the notion that this approach might lead to a general method for the synthesis of $\mathbf{5}$, we set out to determine the scope to produce structurally various products as summarized in Table 2 .

Obtainment of the products can be accounted by the following reaction pathway as illustrated in Scheme 2. In order to prove reaction pathway from $\mathbf{3}$ to $\mathbf{5}$ and $\mathbf{6}$, two facts were obtained: i) $\mathbf{3}$ turned out to be thermally stable ii)

Table 2. Cyclocarbonylation of 3 with $\mathrm{Mo}(\mathrm{CO})_{3}(\mathrm{DMF})_{3}{ }^{a}$

\begin{tabular}{|c|c|c|c|c|}
\hline Entry & Product (5) & & $5: 6$ & Yield, $\%^{b}$ \\
\hline 1 & & $5 \mathbf{a}$ & $87: 13$ & 67 \\
\hline 2 & & $5 b$ & $78: 22$ & 48 \\
\hline 3 & & $5 c$ & $93: 7$ & 75 \\
\hline 4 & & $5 d$ & $85: 15$ & 63 \\
\hline 5 & & $5 e$ & $92: 10$ & 71 \\
\hline 6 & & $5 f$ & $71: 29$ & 44 \\
\hline
\end{tabular}

${ }^{a}$ All reactions were run with DMSO (10 equiv) in $\mathrm{CH}_{2} \mathrm{Cl}_{2}$ at $80^{\circ} \mathrm{C}$ for $6 \mathrm{~h}$ in a sealed tube. ${ }^{b}$ Refer to isolated product 5 .

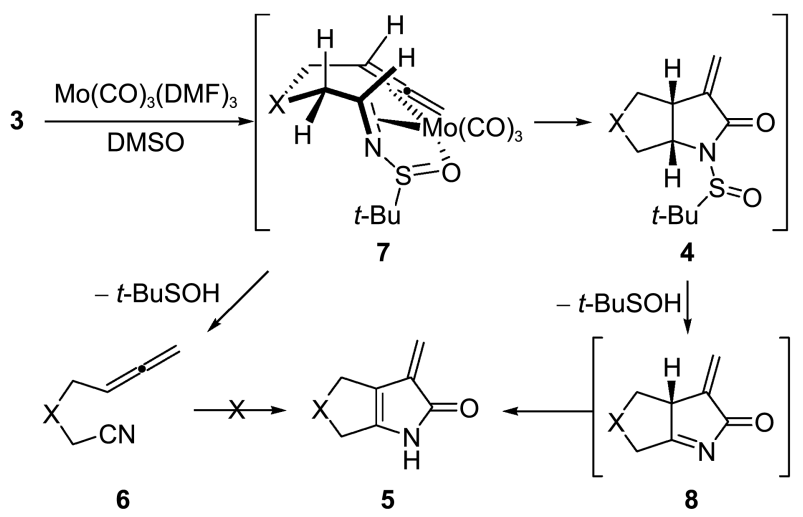

Scheme 2. Reaction pathway.

reaction of 6 under same conditions did not occur. After formation of complex 7 from 3 with $\mathrm{Mo}(\mathrm{CO})_{3}(\mathrm{DMF})_{3}$, reaction might produce 4 and 6 . Subsequent elimination reaction of 4 could take place to afford $\mathbf{5}$ via the formation of $\mathbf{8}$.

In summary, this communication describes synthetic routes to the 3-methylene-1-pyrrol-2-ones $\mathbf{5}$ from allenyl sulfinimides $\mathbf{3}$ with $\mathrm{Mo}(\mathrm{CO})_{3}(\mathrm{DMF})_{3}$ via a $[2+2+1]$-cyclocarbonylation. Studies are in progress to incorporate with diene into multi-cyclic compounds by cycloaddition reaction related to a core skeleton of biologically active natural product s.

Acknowledgments. Generous financial support from the National Research Foundation (2009-0076852, R01-2007$000-20315-0)$ is gratefully acknowledged.

\section{References}

1. (a) Nakamura, I.; Yamamoto, Y. Chem. Rev. 2004, 104, 2127. (b) Zeni, G.; Larock, R. C. Chem. Rev. 2006, 106, 4644.

2. (a) Trost, B. M.; Toste, F. D.; Pinkerton, A. B. Chem. Rev. 2001, 101, 2067. (b) Aubert, C.; Buisine, O.; Malacria, M. Chem. Rev. 2002, 102, 813 .

3. Reviews, see: (a) Trost, B. M. Acc. Chem. Res. 2002, 35, 695. (b) Ma, S. Eur. J. Org. Chem. 2004, 1175.

4. General discussions, see: Hoffmann-Röder, A.; Krause, N. Angew. Chem. Int. Ed. 2004, 43, 1196.

5. Mandai, T. In Modern Allene Chemistry, Vol. 2; Krause, N., Hashmi, A. S. K., Eds.; Wiley-VCH: Weinheim, 2004; pp 925-972.

6. (a) Yu, C.-M.; Hong, Y.-T.; Lee, J. J. Org. Chem. 2004, 69, 8506. (b) Kwon, J.; Gong, S.; Woo, S.-H.; Yu, C.-M. Bull. Korean Chem. Soc. 2009, 30, 773.

7. (a) Yu, C.-M.; Youn, J.; Lee, M.-K. Org. Lett. 2005, 7, 3733. (b) Yu, C.-M.; Youn, J.; Jung, J. Angew. Chem. Int. Ed. 2006, 45, 1553. (c) Kim, S. H.; Oh, S.-J.; Ho, P.-S.; Kang, S.-C.; O, K.-J.; Yu, C.-M. Org. Lett. 2008, 10, 265.

8. (a) Kim, S.-H.; Kang, E.-S.; Yu, C.-M. Synlett 2007, 2439. (a) Kim, S.-H.; Oh, S.-J.; Kim, Y.; Yu, C.-M. Chem. Commun. 2007, 5025.

9. (a) Ferreira, F.; Botuha, C.; Chemla, F.; Perez-Luna, A. Chem. Soc. Rev. 2009, 38, 1162. (b) Robak, M. T.; Herbage, M. A.; Ellman, J. A. Chem. Rev. 2010, 110, 3600.

10. Datta, G. K.; Ellman, J. A. J. Org. Chem. 2010, 75, 6283.

11. (a) Adrio, J.; Carretero, J. C. J. Am. Chem. Soc. 2007, 129, 778. (b) Brummond, K. M.; Curran, D. P.; Mitasev, B.; Fischer, S. J. Org. Chem. 2005, 70, 1745. (c) Cao, H.; Van Ornui, S. G.; Deschamps, J.; Flippen-Anderson, J.; Laib, F.; Cook, J. M. J. Am. Chem. Soc. 2005, 127, 933. 